\title{
Work Analysis of Maritime Passenger Terminals for Particular Region Based on Circos Plot
}

\section{Analiza rada pomorskih putničkih terminala za određenu regiju na temelju kružnog grafikona}

\author{
Srećko Krile \\ University of Dubrovnik \\ Electric Engineering and \\ Computing Department \\ e-mail: srecko.krile@unidu.hr
}

\author{
N. N. Maiorov \\ Saint-Petersburg State University of \\ Aerospace Instrumentation \\ Department of system analysis and logistics \\ Saint-Petersburg, Russia \\ e-mail:nmsoft@yandex.ru
}

DOI 10.17818/NM/2019/2.2

UDK 656.615

627.029

Original scientific paper / Izvorni znanstveni rad

Paper accepted / Rukopis primljen: 4. 3. 2019.

\section{KEY WORDS}

transport hub

marine passenger terminal

passenger traffic

ferry line

circos plot

traffic intensity

into account the mutual influence of the terminals and ferry lines on each other, the task becomes much more complicated. The discrete nature of the initial data, schedules of ship calls which need to be combined into a single array of data, comes to the fore in the study of processes. The process of functioning of an individual terminal with varying degrees of accuracy can be represented as a sequence of several typical design modes, each of which corresponds to a change in a certain set of characteristics and number of ship calls. But when solving problems at the macro-level, the article proposes to use optimization based on the circos plot. The construction of this type of diagram is associated with the fulfillment of certain boundary conditions, which makes it possible to define the boundaries of the region, to study and to form the completeness of the initial data. The object of the study is the interconnection of selected marine passenger terminals and the existing ferry lines. Based on the initial data, transformations were carried out and a circular (circos) plot of relations was constructed. Such diagram takes into account the analysis of the mutual influence of the terminals of one region. The obtained results make it possible to improve the quality of decision making, since a representation of the macro-level planning system of the «marine passenger terminals - ferry lines» is formed within the framework of the selected marine region.

\section{Sažetak}

Gledajući sustavno, dosad je bilo nemoguće posebno promatrati putničke terminale $i$ aktivnosti trajektnih i brodskih linija. Potrebno je istražiti njihov međusobni utjecaj, analizirati intenzitete, uzeti u obzir utjecaj vanjskog okruženja i riješiti probleme predviđanja. Ova okolnost opravdava potrebu za korištenjem novih alata i modela koji omogućuju analizu makro-razine, što obuhvaća sve luke u regiji i dostupne trajektne linije. Za rješavanje problema kratkoročnog prognoziranja, klasa polinomijalnog računa se također preporuča. Međutim, uzimajući u obzir međusobni utjecaj terminala i trajektnih linija jednih na druge, zadatak postaje mnogo složeniji. Diskretna priroda ulaznih podataka, rasporedi ticanja brodova, koje je potrebno kombinirati u jedinstven niz podataka, dovodi do problema pri takvom istraživanju. Proces funkcioniranja za pojedini terminal s različitim stupnjem točnosti, može se prikazati kao niz tipičnih načina modeliranja, od kojih svaki odgovara promjeni u određenom skupu karakteristika i učestalosti ticanja brodova. Pri rješavanju problema na makro-razini, članak predlaže korištenje strukturnog kružnog grafikona. Konstrukcija ovog grafikona povezana je s ispunjenjem određenih rubnih uvjeta, što omogućuje definiranje granica regije, proučavanje i oblikovanje cjelovitosti početnih podataka. Cilj istraživanja su odabrani brodski terminali i postojeće trajektne linije. Na temelju početnih podataka izvršene su transformacije i konstruiran je kružni grafikon njihovih odnosa. Takav grafikon uzima u obzir analizu međusobnog utjecaja terminala. Dobiveni rezultati omogućuju poboljšanje kvalitete odlučivanja, pošto se u okviru odabrane morske regije formira sustav planiranja makro-razine «pomorskih putničkih terminala - trajektnih linija».

\section{KLJUČNE RIJEČI}

prometno čvorište pomorski putnički terminal putnički promet trajektna linija strukturni kružni grafikon prometni intenzitet 


\section{INTRODUCTION / Uvod}

Modern processes in the economy directly affect the development and changes of seaports, terminals and transport systems. It should be noted that any marine passenger terminal has historically been formed and operates under the influence of a certain set of unique factors that determine the uniqueness of the port today. In view of the introduction of new intelligent systems in transport, the introduction of vehicle traffic monitoring systems, the tendency to increase the size of cruise ships, and a number of others, modern requirements for the operation of marine passenger terminals are increasing. Also, decision time is shorter and shorter. It is under the influence of changes in the external environment, often serving as a stimulus, that the process of updating the infrastructure of passenger terminals and launching mechanisms to attract new ferry and cruise lines to the port begins.

The key conditions for the stable operation of the port is the growth of the tourist attractiveness of the region, an increase in the passenger traffic and attendant cargo traffic between the ports and, as a result, an increase in the intensity of cruise and ferry ship calls. The port infrastructure should be able to handle the input flow of ships without failures and possible delays. Therefore, in this vein, the task of operational forecasting the number of cruise ships and estimating congestion is extremely important.

In the articles [1,2,3] mathematical models for forecasting are presented and on their basis the task of forecasting the intensity of cruise and ferry ships for 2018-2019 for the Passenger Port of Saint Petersburg "Marine Facade" is solved. The presented realized task in the class of polynomial models and the conditions for achieving prediction accuracy can be used at any desired forecast interval. In case of changing the parameters of the environment, it is necessary to recalculate. At the same time, the obtained dependencies contain information on the basis of which only a specific specified passenger terminal can be evaluated.

The class of problems of forecasting polynomial models does not allow to investigate the mutual influence of terminals and passenger and ports of the region on each other. This question is extremely interesting when studying the situation of competition in the market for passenger traffic and cargo traffic. This task is relevant for the regions of the Adriatic and Baltic Seas. Due to the proximity of the ports and terminals in the border countries and the proximity of various cultural and historical sites, the uniqueness of these sea regions is revealed.

Ferries in Croatia connect the Croatian coast with all inhabited islands. Ferries to Croatia connect Croatian ports with Italy and nearest countries. The major Croatian passenger (cruise and ferry) ports are Split, Zadar, Rijeka, Šibenik and Dubrovnik. Dubrovnik is an Adriatic Sea cruise port and city in Croatia, and one of Europe's historically most prominent and popular vacation travel destinations. According to the statistical data from EUROSTAT [4], given in table 1, there is a significant increase in passengers transported to/from main ports of Croatia in quarterly data.

Ferries in Baltic Sea, passenger shipping on the serve as the backbone elements of the Baltic transnational macro-region $[5,6,7]$. By the Baltic macro-region, we will mean an integrated international region that includes the entire set of economic activities and represents a network model of cooperation with the presence of both horizontal and vertical links, with the efforts of 52 seaports out of 184, providing services for both cruise and ferry transportation of passengers. At the same time, it is possible to note a tendency towards a change in interests among tourists, caused by an increase in interest in the cultural layer of the northern countries. Over the past three years, there has been a significant increase in cruise lines that the ports of the Baltic Sea are added to their routes. The article [8] presents the solution of the routing problem for cruise and ferry lines and presents a methodological analysis of possible changes.

For such regions, any actions or new transport decisions taken in one country or region can very quickly affect the development of other territories or the region as a whole, both positively and negatively. Due to the close relationship with other passenger ports, it is necessary to have a toolkit that would allow the results to be associated with data from other ports and to determine the mutual influence.

\section{RESEARCH MODEL FOR PASSENGERS PORTS AND TERMINALS / Model za istraživanje sustava Putničke luke i terminali}

Perform a representation of the model of the interaction of terminals in the form of a fig. 1

On figure $1 \mathrm{X}(\mathrm{t})$ represents the dynamic behavior of the passenger traffic, which enters the passenger terminal system. Each region has a limited set of passenger terminals $(\mathrm{Y}(\mathrm{N})$ ). Ferry lines are organized between the terminal system both on a regular basis and seasonally.

To solve the problem of studying the work of the «marine passenger terminal - ferry line» system, it is necessary to introduce the following restrictions:

1. Of the many ports in the region, only passenger terminals are selected and the terminals are ranked by intensive ship calls;

Table 1 Passengers transported to/from main ports - Croatia - quarterly data (in thousand passengers) Tablica 1. Prevezeni putnici između glavnih luka u Hrvatskoj (kvartalno - u tisućama putnika)

\begin{tabular}{|c|c|c|c|c|c|c|c|c|c|c|}
\hline Ports & 2016/Q3 & 2016/Q4 & 2017/Q1 & 2017/Q2 & 2017/Q3 & 2017/Q4 & 2018/Q1 & 2018/Q2 & 2018/Q3 & 2018/Q4 \\
\hline Dubrovnik & 691 & 103 & 38 & 357 & 777 & 117 & 30 & 374 & 827 & 130 \\
\hline Poreč & 150 & 10 & 0 & 56 & 160 & 11 & 0 & 58 & 157 & 14 \\
\hline Preko & 706 & 328 & 294 & 451 & 724 & 324 & 283 & 451 & 737 & 323 \\
\hline Pula & 242 & 55 & 20 & 168 & 231 & 58 & 21 & 173 & 248 & 62 \\
\hline Rovinj & 29 & 3 & : & 10 & 38 & 1 & : & 17 & 59 & 4 \\
\hline Šibenik & 286 & 60 & 37 & 139 & 286 & 60 & 34 & 154 & 276 & 62 \\
\hline Split & 2170 & 594 & 441 & 1117 & 2190 & 591 & 445 & 1212 & 2369 & 625 \\
\hline Zadar & 918 & 378 & 333 & 542 & 960 & 372 & 322 & 551 & 980 & 375 \\
\hline
\end{tabular}




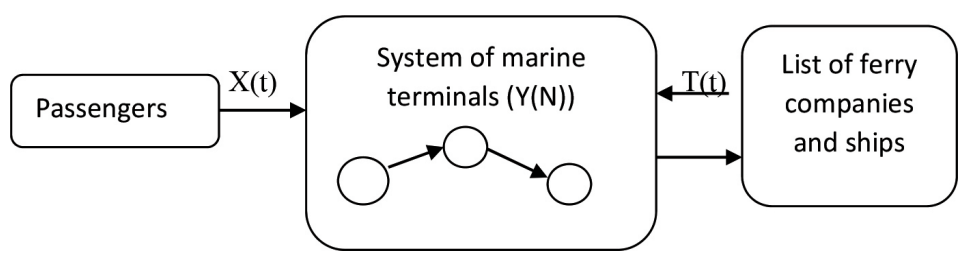

Figure 1 Representation of the interaction of the systems «Terminal-ferry line» Slika 1. Prezentacija interakcije u sustavu Terminal - trajektna linija"

2. when considering the statistics of each port operation, data taken at a close time is selected and this discrete state is selected as the main one at $T_{0^{\prime}}$;

3. source terminals form two data arrays:

- the first array is one-dimensional and consists of passenger terminals $n$ (example based on the ports of the Baltic region (St. Petersburg, Copenhagen and others))

$F_{\text {pass.ter min al }}\left(N_{i}\right)=\left\{F_{\text {Helsingborg }} ; F_{\text {Elsinore (Helsing) }} ; F_{\text {St. Petersburg }} ; \ldots ; F_{\text {Copenhagen }}\right\}$

where $F_{\text {St. Petersburg }}$ - number of calls at the port; $N$ - number of passenger terminals in the region.

- the second array is a two-dimensional array, the elements of which reflect the intensities of ferry or cruise ships between specified ports at a selected discrete point in time. In practice, the values of both direct and reverse routes are entered.

$F_{\text {ferry_line }}\left(F_{i}, F_{j}\right)=\left\{\begin{array}{ll}N_{00}\left(F_{\text {Helsingborg }} ; F_{\text {Helsingborg }}\right) & N_{01}\left(F_{\text {Helsingborg }}, F_{\text {St. Peterburg }}\right) \\ N_{10}\left(F_{\text {St. Petersburg }}, F_{\text {Helsingborg }}\right) & N_{11}\left(F_{\text {St. Petersburg }}, F_{\text {St. Petersburg }}\right) \\ \ldots \ldots . . & \end{array}\right\}$ (2)

where is $F_{i}$ - port of departure; $F_{j}$ - port of destination; $N\left(F_{\text {St. Petersburg }}, F_{\text {Helsingborg }}\right)$ - the numerical value of the intensity of ships at a given discrete point in time between passenger terminals.

4. cruise and ferry intensities are taken at a selected time $T_{0}$. When deciding to predict any cruise ship call at the port belongs to the full group of events.

$$
\sum_{i=1}^{N} P F_{\text {ferry_line }}\left(F_{i}, F_{j}\right)=1
$$

Based on the formation of the conditions for the full group of events, the boundaries of the sample are determined.

For Baltic region, based on the analysis of the intensity of calls to passenger ports, the following terminals, as most significant, can be distinguished: Helsingborg, Elsinore (Helsingør), Helsinki, Stockholm, Puttgarden / Fehmarn, Tallinn, Turku, Mariehamn, St. Petersburg, Rostock, Gothenburg, Ystad, Trelleborg, Kiel, Copenhagen and several others. For Croatian region the following terminals, as most significant, can be distinguished: Dubrovnik, Preko, Split, Zadar, Pula.

\section{MODEL IN THE FORM OF THE CIRCULAR RELATIONSHIP DIAGRAM FOR SYSTEM OF PASSENGER TERMINALS IN THE REGION / Model prikaza uz pomoć kružnog grafikona za sustav putničkih terminala u regiji}

When the above conditions are met, the possibility of practical construction of circular diagrams of relations opens up. When performing an analysis of the intensity of the transport system or the workload of nodes, the functionality is widely used, most often presented in graphical or tabular form or, more rarely, in the form of two-factor (multi-factor) functions. But this approach does not allow to analyze the entire system in a complex at the macro-level, in this case, taking into account the selected passenger terminals. This approach allows you to use system dynamics as a method for studying the behavior of the system. System dynamics is a set of principles and methods for analyzing dynamic controlled systems with feedback and their application for solving technical problems based on a flowchart. But system dynamics can be used only in the study of the interaction of two terminals.

On the other hand, the pie chart is a tool based on the definition of logical relationships between the various data of an existing system. As a rule, the relationship diagram is used in conjunction with the affinity diagram, since allows you to build the causes identified with its help in a logical chain. In turn, the affinity diagram is intended for grouping and organizing a large amount of source data. Grouping occurs on the principle of uniformity of information. In our case, this diagram is already determined by a one-dimensional array of existing passenger terminals and the presence of the existing route network at the selected discrete point in time.

With this approach, with diagram of port interaction (circos plot), we provide a structured approach to the analysis of complex interactions between passenger terminals, which is its significant strength. At the same time, the diagram on its elements allows placing additional analytical information (Fig. 2), e.g. work intensity, workload, possible failures and other quality indicators for the terminal, school and other percentage data. The main element of the diagram is a circle, which cyclically combines other elements. In the case of two directions between passenger ports, but having different intensities, a single arc, which displays both directions, is introduced.

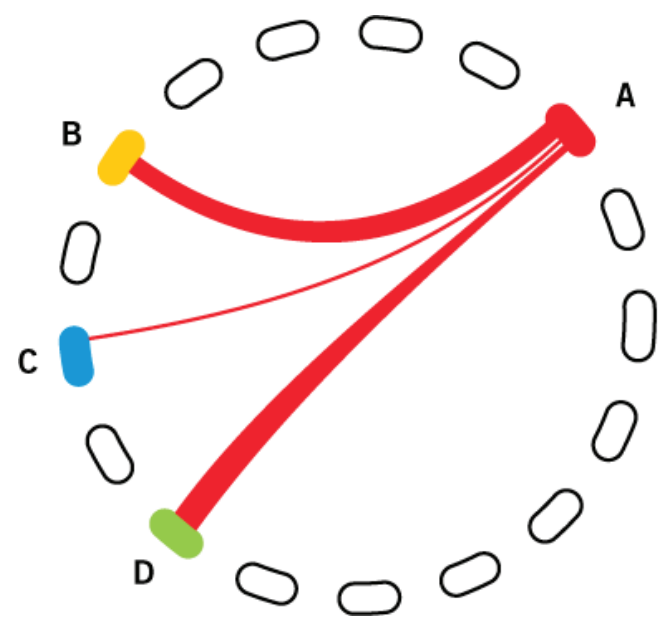

Figure 2. Circos plot introduces interaction between ports for the study of marine passenger terminals

Slika 2. Interakcjijski kružni grafikon za istraživanje pomorskih putničkih terminala 
Based on the application of these diagrams, it is possible at a qualitatively new level to present the interaction of the «maritime passenger terminal - cruise / ferry line» systems. When changing data over time, we can establish mutual influence on other passenger ports in the Adriatic and Baltic regions.

\section{PRACTICAL USE OF CIRCULAR DIAGRAM (CIRCOS PLOT) FOR THE SYSTEM OF MARINE PASSENGER TERMINALS \\ Način prikaza kružnim grafikonom međusobnih odnosa pomorskih putničkih terminala}

For the Baltic and Adriatic regions, we select the ferry traffic intensity from 11 to 17 February 2019 as the time interval for the research $[9,10]$. Of course, the time interval can vary, depending on the objectives of the study. Baseline data is selected from the cruise ship and ferry vessel call schedules that are publicly available. Based on the selected interval, ferry destinations between the Baltic Sea countries were compiled, as shown in Table 2 and Table 3. For Croatian terminals input data was selected from the schedules of ferry companies and according to resources [11]. One interesting research for time schedule of small ferry destinations can be seen in light of "smart islands" initiative [14].

Table 2 Intensities of ferry ships in the Baltic Sea Tablica 2. Intenzitet trajektnih linija u Baltičkom moru

\begin{tabular}{|l|c|c|c|c|}
\hline $\begin{array}{c}\text { Passengers } \\
\text { terminals }\end{array}$ & Helsinki & Stockholm & St. Petersburg & Tallinn \\
\hline Tallinn & 15 & 3 & 0 & 0 \\
\hline Helsinki & 0 & 3 & 2 & 14 \\
\hline Stockholm & 3 & 0 & 0 & 2 \\
\hline St. Petersburg & 2 & 0 & 0 & 1 \\
\hline
\end{tabular}

Table 3 Intensities of ferry ships in the Adriatic Sea Tablica 3. Intenzitet trajektnih linija u Jadranskom moru

\begin{tabular}{|l|c|c|c|c|}
\hline $\begin{array}{c}\text { Passengers } \\
\text { terminals }\end{array}$ & Bari & Venice & Trieste & Ancona \\
\hline Dubrovnik & 2 & 0 & 0 & 0 \\
\hline Pula & 0 & 2 & 0 & 0 \\
\hline Rovinj & 0 & 1 & 2 & 0 \\
\hline Split & 0 & 0 & 0 & 3 \\
\hline
\end{tabular}

The presented intensity values define the full group of events. New dynamic data in the system will not be added. The original tabular data is converted into a matrix form $[12,13]$ and the result is the desired annular diagram of relations with regard to the analysis of the shares of routes in the directions (Fig. 3,4). Based on the initial data, a specialized file is generated that is loaded into the instrumental environment of circus.

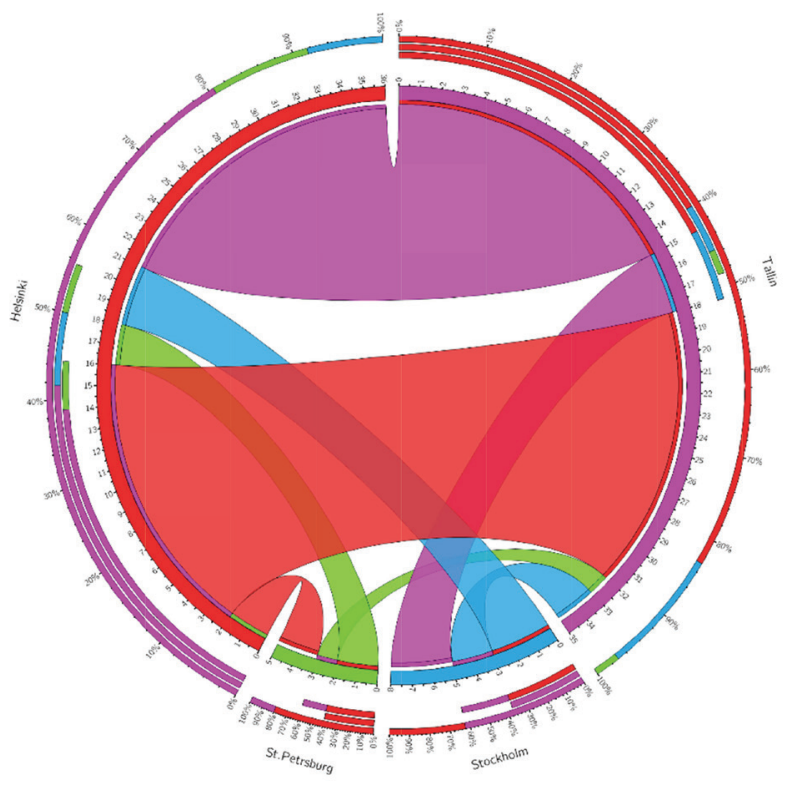

Figure 3. Graph representation of ferry traffic intensities between selected ports of the Baltic Sea

Slika 3 Grafički prikaz intenziteta trajektnog prometa između odabranih luka Baltičkog mora

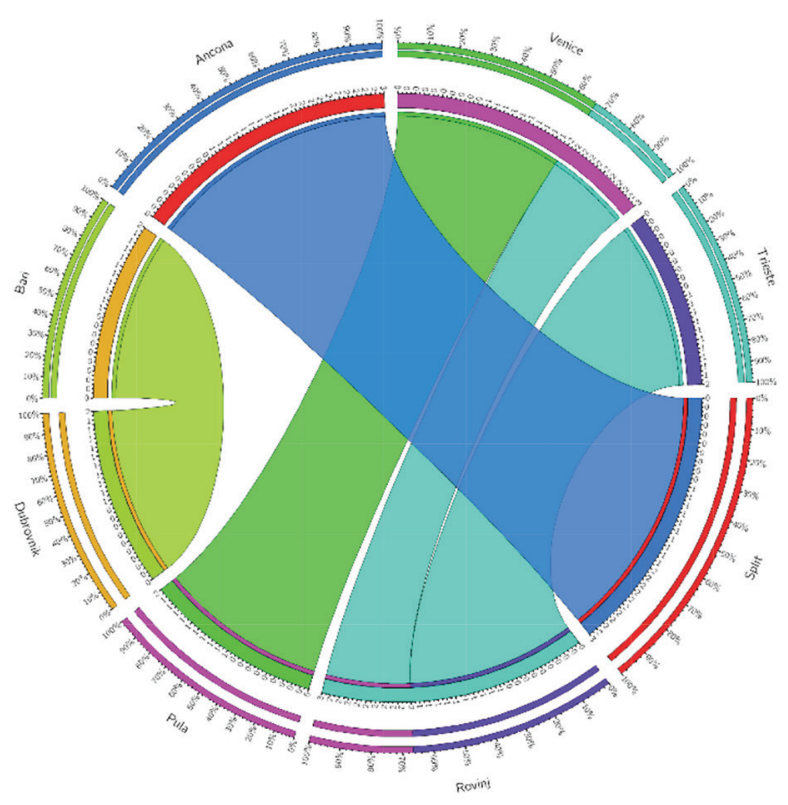

Figure 4. Graph representation of ferry traffic intensities between selected ports of the Adriatic Sea

Slika 4. Grafički prikaz intenziteta trajektnog prometa između odabranih luka Jadranskog mora

The graph representation also contains analytical information on the mutual influence of ports, presented in the form of corresponding circular scales. This analytical material makes it possible to predict decision making already at the macro-level of planning, since it also provides information on the mutual influence of terminals. As a result, the use of circular diagram (circos plot) makes it possible at the macro-level to investigate the operation of the «maritime passenger terminal - ferry line» system. 


\section{CONCLUSION / Zaključak}

Based on the need for a comprehensive study of the operation of marine passenger terminals, and analysis of their mutual influence, the need to use circular diagrams (circos plot) for representation of traffic influence between ports is substantiated. To obtain the correct simulation results, it is necessary to fulfill a number of conditions and limitations. When forming the source data, the discrete approach is justified. All available data should form a complete group of events that fully describe the interaction of the "maritime passenger terminal - ferry line" at a selected discrete point in time. The range of tasks for the macro-level study of sea port systems has been substantiated. The features of circular diagrams of connections, their positive and negative sides are considered. Based on the initial data, a truncated terminal sample was formed ("Passenger Port St. Petersburg", passenger terminals of Tallinn, Stockholm and Helsinki and for Adriatic region Dubrovnik terminal, Split, Pula, Rovinj). Taking into account the actual intensity of ferry traffic, the matrix form of the initial data presentation was implemented and then the required circular diagram (circos plot) was constructed, which will assess the mutual influence of the passenger terminals. The proposed study approach can be used for any number of passenger terminals and the model can be scaled. When a system is formed from data diagrams built over a selected time interval, it is possible to justify system changes, which cannot be determined by working technique with separate tables. The result should be used in conjunction with forecasting in the class of polynomial models, thereby enhancing the solution for the problem of providing the necessary port capacity and reasonable modernization of the infrastructure of sea passenger ports and terminals.

\section{REFERENCES / Literatura}

[1] Maiorov, N. N., Fetisov, V. A. Improvement of the quality of the sea passenger terminal based on methods of forecasting. Our sea. 2018. Vol 65. No. 3. P. 135140

[2] Krile, S., Maiorov N., Fetisov V., Forecasting the operational activities of the sea passenger terminal using intelligent technologies, Transport Problems, 2018 Vol.13 (Issue 1), pp. 27-36. DOI: 10.21307/tp.2018.13.1.3

[3] Yan, S., Chen, H. C., Chen, Y. H. \& Lou, T. C. Optimal scheduling model for ferry companies under alliances. Journal of Marine Science and Technology. 2007. Vol 15. No 1. PP. 53-66.

[4] Passengers transported to/from main ports - Croatia - quarterly data. Available at: http://appsso.eurostat.ec.europa.eu/nui/show.do?dataset=mar_pa_qm hr\&lang=en (accessed 11 February 2019)

[5] Mezhevich N. M. Baltijskij region i Rossiya na Baltike: specifika pozicionirovaniya [Baltic region and Russia in the Baltic: positioning specifics ] Available at: https://www.ut.ee/ABVKeskus/sisu/publikatsioonid/2004/pdf/VF-B.pdf (accessed 15.11.2018)

[6] Baltic Port list 2006. Annual cargo statistic of ports in the Baltic Sea region/ A publication from the center for maritime studies university of Turku: - Turku, 2012. 120 p.

[7] Baltic Port Barometer 2012 Available at: http://www.sadamateliit.ee/avalikteave/Baltic-Port-Barometer-2012 (accessed 15.11.2018)

[8] Chládek, P., Smetanová, D., Krile, S., On some aspects of graph theory for optimal transport among marine ports. Scientific Journal of Silesian University of Technology. Series Transport .m 2018 Vol. 101, pp. 37-45. DOI: 10.20858/sjsutst.2018.101.4.

[9] Directferries.com Available at: https://www.directferries.com/routes.htm (accessed 11.02.2019).

[10] HELCOM.fi. Available at: http://maps.helcom.fi/website/AISexplorer/ (accessed 11.02.2019).

[11] PORTDUBROVNIK.HR. Available at: http://portdubrovnik.hr/statistika/?id Kat=1\&godina $=2018$ (accessed 11.02.2019).

[12] Wang J. M. The study and analysis of model algorithm for dynamic origindestination matrix estimation and prediction. Ningxia Engineering Technology. 2002. Vol. 1. No. 4. PP. 362-365.

[13] Circos. Available at: https://sourceforge.net/projects/jcircos/ (accessed 11.02.2019).

[14] Krile, S., Mišković, D., Optimal Use of Container Ships for Servicing Among Small Ports, Naše more (Our Sea), 2018 Vol. 65, No 1, pp.18-23, DOI: 10.17818/ $\mathrm{NM} / 2018 / 1.3$ 